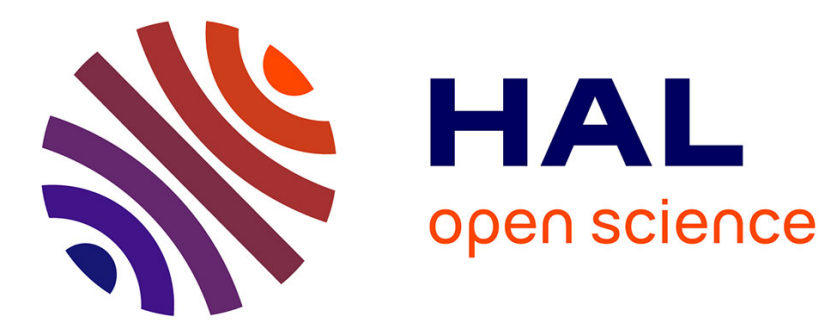

\title{
Biochemical analysis of $\alpha$-synuclein extracted from control and Parkinson's disease colonic biopsies
}

Anne-Gaëlle Corbillé, Cécile Preterre, Malvyne Rolli-Derkinderen, Emmanuel Coron, Michel Neunlist, Thibaud Lebouvier, Pascal Derkinderen

\section{- To cite this version:}

Anne-Gaëlle Corbillé, Cécile Preterre, Malvyne Rolli-Derkinderen, Emmanuel Coron, Michel Neunlist, et al.. Biochemical analysis of $\alpha$-synuclein extracted from control and Parkinson's disease colonic biopsies. Neuroscience Letters, 2017, 641, pp.81-86. 10.1016/j.neulet.2017.01.050 . hal-03153604

\section{HAL Id: hal-03153604 \\ https://cnrs.hal.science/hal-03153604}

Submitted on 3 Mar 2021

HAL is a multi-disciplinary open access archive for the deposit and dissemination of scientific research documents, whether they are published or not. The documents may come from teaching and research institutions in France or abroad, or from public or private research centers.
L'archive ouverte pluridisciplinaire HAL, est destinée au dépôt et à la diffusion de documents scientifiques de niveau recherche, publiés ou non, émanant des établissements d'enseignement et de recherche français ou étrangers, des laboratoires publics ou privés. 


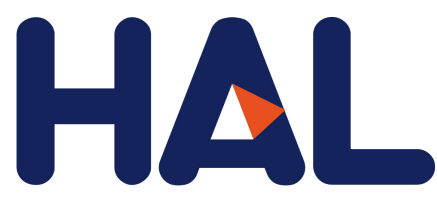

archives-ouvertes

\section{Biochemical analysis of $\alpha$-synuclein extracted from control and Parkinson's disease colonic biopsies}

Anne-Gaëlle Corbillé, Cécile Preterre, Malvyne Rolli-Derkinderen, Emmanuel Coron, Michel Neunlist, Thibaud Lebouvier, Pascal Derkinderen

\section{To cite this version:}

Anne-Gaëlle Corbillé, Cécile Preterre, Malvyne Rolli-Derkinderen, Emmanuel Coron, Michel Neunlist, et al.. Biochemical analysis of $\alpha$-synuclein extracted from control and Parkinson's disease colonic biopsies. Neuroscience Letters, Elsevier, 2017, 641, pp.81-86. 10.1016/j.neulet.2017.01.050 . hal03153604

\section{HAL Id: hal-03153604 \\ https://hal-cnrs.archives-ouvertes.fr/hal-03153604}

Submitted on 3 Mar 2021

HAL is a multi-disciplinary open access archive for the deposit and dissemination of scientific research documents, whether they are published or not. The documents may come from teaching and research institutions in France or abroad, or from public or private research centers.
L'archive ouverte pluridisciplinaire HAL, est destinée au dépôt et à la diffusion de documents scientifiques de niveau recherche, publiés ou non, émanant des établissements d'enseignement et de recherche français ou étrangers, des laboratoires publics ou privés. 
Research article

\title{
Biochemical analysis of a-synuclein extracted from control and Parkinson's disease colonic biopsies
}

\author{
Anne-Gaëlle Corbillée,b,c,1 Cécile Preterree,b,c,1, Malvyne Rolli-Derkinderen ${ }^{\mathrm{a}, \mathrm{b}, \mathrm{d}}$, \\ Emmanuel Coronn ${ }^{a, b, \mathbb{a}}$, Michel Neunlist ${ }^{\mathrm{a}, \mathrm{b}, \mathrm{d}}$, Thibaud Lebouvier ${ }^{-}$, Pascal
}

${ }^{a}$ Inserm, U913, Nantes F-44035, France

${ }^{\mathrm{b}}$ Nantes University, Nantes F-44035, France

${ }^{\mathrm{c}}$ CHU Nantes, Department of Neurology, Nantes F-44093, France

${ }^{\mathrm{d}} \mathrm{CHU}$ Nantes, Institut des Maladies de l'Appareil Digestif, Nantes F-44093, France

${ }^{\mathrm{e}}$ Centre Mémoire de Ressources et de Recherche (CMRR), Lille F-59037, France

\section{h i g h 1 igh t s}

- Alpha-synuclein deposits are found in the gut in PD.

- Alpha-synuclein expression levels and phosphorylation status were analyzed by biochemical means in 17 PD patients.

- No differences in the expression levels, phosphorylation and aggregation status of alpha-synuclein was observed between controls and PD.

- Our study suggests that the biochemical methods tested are not adequate for the prediction of PD using gastrointestinal biopsies.

artic 1 e in fo

\section{Article history:}

Received 20 December 2016

Received in revised form 18 January 2017

Accepted 20 January 2017

Available online 23 January 2017

\section{Keywords:}

Alpha-synuclein

Phosphorylation

Western blot

Two-dimensional immunoblot

Gastrointestinal biopsy

Enteric nervous system a b s t $\mathbf{r}$ a c t

Lewy bodies and neurites, the pathological hallmarks found in the brain of Parkinson's disease (PD) patients, are primarily composed of aggregated and hyperphosphorylated alpha-synuclein. The observation that alpha-synuclein inclusions are also found in the gut of the vast majority of parkinsonian patients has led to an increasing number of studies aimed at developing diagnostic procedures based on the detection of pathological alpha-synuclein in gastrointestinal biopsies. The previous studies, which have all used immunohistochemistry for the detection of alpha-synuclein, have provided conflicting results. In the current survey, we used a different approach by analyzing the immunoreactivity pattern of alpha-synuclein separated by one- and two-dimensional electrophoresis, in colonic biopsies from PD subjects and healthy individuals. We did not observe any differences between controls and PD in the expression levels, phosphorylation or aggregation status of alpha-synuclein. Overall, our study suggests that the two biochemical methods tested here are not adequate for the prediction of PD using gastrointestinal biopsies. Further studies, using other biochemical approaches, are warranted to test whether there exists specific forms of pathological alpha-synuclein that distinguish PD from control subjects.

\section{Introduction}

In recent years, the neuronal 140 amino acid protein alphasynuclein has attracted much attention because of its involvement

\footnotetext{
* Corresponding author at: Inserm U913, 1 place Gaston Veil, 44035 Nantes,

E-mail addresses: derkinderenp@yahoo.fr, pascal.derkinderen@chu-nantes.fr (P. Derkinderen)
}

${ }^{1}$ Equal contributors. in neurodegenerative diseases and more specifically in Parkinson's disease (PD). Five independent mutations in human alphasynuclein cause familial PD, and wild type alpha-synuclein is one of the main components of Lewy bodies, the characteristic intraneuronal inclusions found in the brain of parkinsonian patients [1]. When deposited in Lewy bodies, alpha-synuclein is aggregated and hyperphosphoryaled at serine $129[2,3]$.

Alpha-synuclein inclusions that resemble those observed in the brain are also found in the gut of the vast majority of PD patients $[4,5]$. These findings prompted a substantial amount of research to determine if the immunohistochemical detection of aggregated 
Table 1

Demographic data for patients with Parkinson's disease (PD).

\begin{tabular}{llll}
\hline Patient number & Gender & Age $(\mathrm{y})$ & Disease duration $(\mathrm{y})$ \\
\hline PD1 & F & 56 & 7 \\
PD2 & F & 64 & 10 \\
PD3 & M & 67 & 13 \\
PD4 & F & 55 & 5 \\
PD5 & M & 71 & 12 \\
PD6 & M & 67 & 9 \\
PD7 & M & 70 & 14 \\
PD8 & F & 70 & 11 \\
PD9 & F & 53 & 6 \\
PD10 & F & 52 & 8 \\
PD11 & M & 58 & 10 \\
PD12 & F & 72 & 3 \\
PD13 & F & 48 & 7 \\
PD14 & F & 69 & 12 \\
PD15 & M & 63 & 8 \\
PD16 & F & 61 & 7 \\
PD17 & M & 62 & 6 \\
\hline
\end{tabular}

Table 2

Demographic data for control subjects. CRC: colorectal cancer.

\begin{tabular}{llll}
\hline Control number & Gender & Age $(\mathrm{y})$ & Reason for colonoscopy \\
\hline C1 & F & 61 & CRC screening \\
C2 & F & 67 & Rectorrhagia \\
C3 & F & 63 & CRC screening \\
C4 & M & 45 & CRC screening \\
C5 & F & 19 & Abdominal pain \\
C6 & M & 76 & CRC screening \\
C7 & F & 63 & CRC screening \\
C8 & M & 62 & CRC screening \\
C9 & F & 69 & CRC screening \\
C10 & F & 63 & CRC screening \\
C11 & M & 72 & CRC screening \\
C12 & F & 69 & CRC screening \\
C13 & M & 74 & CRC screening \\
\hline
\end{tabular}

and/or phosphorylated alpha-synuclein in routine gastrointestinal biopsies could be used for in vivo pathological diagnosis of PD [6-11]. These studies gave conflicting results regarding the sensitivity and specificity of colonic biopsies for the detection of pathological alpha-synuclein inclusions. This was confirmed by a more recent multi-center study, which showed limited diagnostic power of quantifying alpha-synuclein deposition in gastrointestinal biopsies by immunohistochemistry [12]. No studies have yet used biochemical methods such as immunoblotting to detect pathological alpha-synuclein in gastrointestinal biopsies, despite the generally higher sensitivity of these techniques when compared to immunohistochemistry. We therefore undertook the current study to determine if analysis of alpha-synuclein expression and its phosphorylation by one- and two-dimensional immunoblotting would allow the differentiation of colonic samples from PD subjects relative to healthy controls.

\section{Patients and methods}

\subsection{Human colonic biopsies and brain samples}

Seventeen patients with PD who were diagnosed according to the United Kingdom PD Society Brain Bank criteria (Table 1, mean age 62.3 7.7) and 13 healthy subjects (Table 2, mean age $61+15)$ participated in the study. Control subjects underwent a colonoscopy for colorectal cancer screening or for investigation of gastrointestinal symptoms (Table 2). All controls subjects underwent a detailed neurological examination to rule out PD symptoms and cognitive deficiency. Biopsies were taken in the sigmoid/descending colon during the course of a rectosigmoidoscopy for PD. The study protocol was approved by the local Committee on Ethics and Human Research (Comité de Protection des Personnes Ouest IV and VI), conformed to the Code of Ethics of the World Medical Association (Declaration of Helsinki) and was registered on ClinicalTrials.gov (identifier NCT01353183 and NCT01748409). Written informed consent was obtained from each patient and from each normal volunteer. Biopsies were snap frozen in liquid nitrogen at the time of collection and stored at $-80^{\circ} \mathrm{C}$ until required. Samples of frozen temporal cortex from twopostmortem humanbrains, one with dementia with Lewy bodies (DLB) and one devoid of neurodegeneration, were obtained from the Neuropathology Department of Angers (Dr. FranckLetournel).

\subsection{One-dimensional immunoblotting}

The biopsies from $10 \mathrm{PD}$ patients (Table 1, PD1 to PD10) and 9 control subjects (Table 2, C1-C9) were lysed in NETF buffer (100 mM NaCl, $5 \mathrm{mM}$ EDTA, $50 \mathrm{mM}$ Tris-Cl, $\mathrm{pH}$ 7.4, and $50 \mathrm{mM} \mathrm{NaF}$ ) containing 1\% (v/v) Igepal CA-630 (Sigma-Aldrich, Saint-Quentin Fallavier, France), phosphatase inhibitor cocktail II (Roche, Neuilly sur Seine, France) and protease inhibitor cocktail (Roche), homogenized using the "Precellys 24" tissue homogenizer (Bertin technologies, Saint Quentin-en-Yvelines, France),

sonicated and centrifugated at $16,000 \mathrm{~g}$ for $20 \mathrm{~min}$ at $4{ }^{\circ} \mathrm{C}$. Supernatants were analyzed by Western Blot as described previously [13] using rabbit polyclonal anti-alpha-synuclein (C20)-R (Santa Cruz Biotechnology, Heidelberg, Germany, 1:1000) and mouse monoclonal anti-alpha-synuclein Syn-1 (BD Bioscience, Le pont de Claix, France, 1:1000) antibodies to detect total alpha-synuclein, a mouse monoclonal Psyn\#64 (Wako, Sodioba, France, 1:500) antibody for the detection of phosphorylated alpha-synuclein and mouse monoclonal antibody anti-Protein Gene Product 9.5 (PGP 9.5; Ultraclone, Isle of Wight, UK, 1:1000) as a general neuronal marker. Enhanced membrane retention of alpha-synuclein was achieved by treating the sample lysate with the cross linker dithiobis[succinimidylpropionate] (DSP) (Sigma-Aldrich, Saint-Quentin Fallavier, France) at $1 \mathrm{mM}[13,14]$. The relevant immunoreactive bands were quantified with laser-scanning densitometry and analyzed using NIH Image $\mathbf{J}$ software. The abundance of total alpha-synuclein was normalized to the amount of PGP 9.5 in each sample, and is expressed as percentage average control. Amounts of phosphorylated alpha-synuclein were normalized to total alphasynuclein in each sample. All data shown are mean standard error of the mean (SEM). For statistical comparison between groups, a Mann-Whitney test was performed. Differences were deemed statistically significant if $\mathrm{p}<0.05$.

\subsection{Two-dimensional immunoblotting}

The remaining biopsies (7 PD, PD11-PD17 and 4 controls, C10-C13, Tables 1 and 2, respectively) were lysed in UTC buffer (7 $\mathrm{M}$ urea, $2 \mathrm{M}$ thiourea, 4\% CHAPS, all from Sigma) containing $0.8 \%$ ZOOM $^{\circledR}$ Carrier 3-10 or 4-7 ampholyte buffer (NuPAGE, Life technologies, Cergy-Pontoise, France), $60 \mathrm{mM}$ dithiothreitol (DTT) (Sigma) and protease inhibitor cocktail (Roche), then homogenized using the "Precellys 24" tissue homogenizer (Bertin technologies, Saint Quentin-en-Yvelines, France). Samples (48 $\mu \mathrm{l})$ were then diluted in a rehydration sample buffer with a trace of bromophenol blue and Isoelectric focusing was performed using the ZOOM $^{\circledR}$ IPGRunner ${ }^{\mathrm{TM}}$ System on $3-10$ or $4-7$ immobilized $\mathrm{pH}$ Gradient gels (Life technologies). Gels were equilibrated twice for 15 min with Lithium dodecyl sulfate Sample Buffer (NuPage). The first equilibration step contained $50 \mathrm{mM}$ DTT and the second $125 \mathrm{mM}$ iodoacetamide (Sigma). Lysates were separated on 4 $12 \%$ sodium dodecyl sulfate polyacrylamide gel electrophoresis and proteins electrotransfered to polyvinylidene difluoride (PVDF) membranes (NuPAGE, Life technologies). Post-transfer membranes 


\section{A}
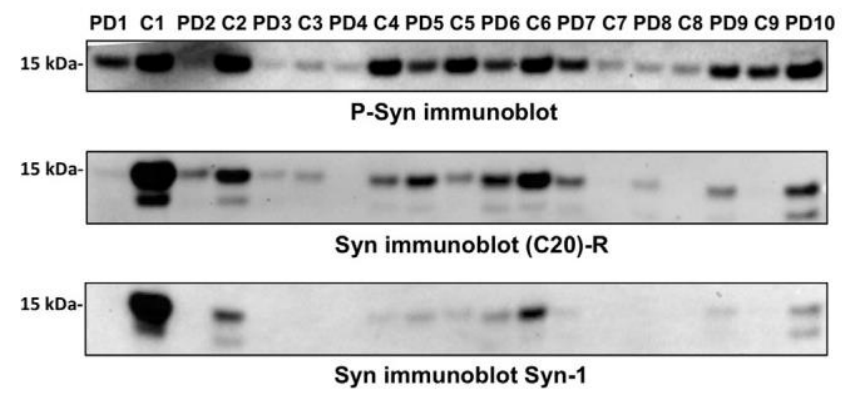

$28 \mathrm{kDa}-$

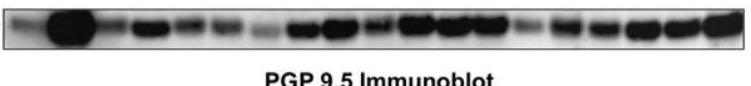

PGP 9.5 Immunoblot
B

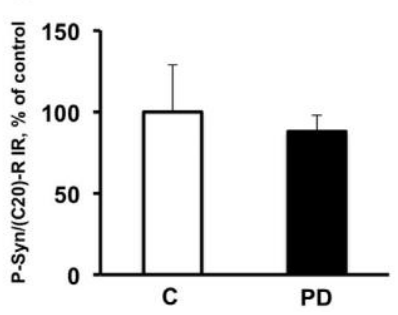

C

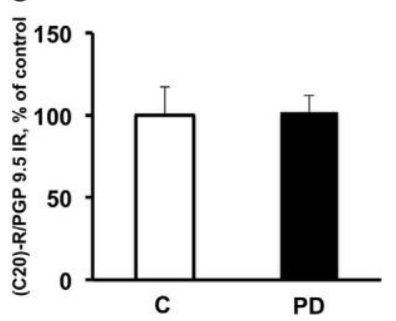

Fig. 1. There are no differences in the expression levels or phosphorylation state of alpha-synuclein in colonic biopsies between control subjects and patients with Parkinson's disease. (A) Colonic biopsies from 10 PD patients (Table 1, PD1-PD10) and 9 control subjects (Table 2, C1-C9) were lysed in NETF/Igepal CA-630 buffer. Biopsy lysates $(20 \mu \mathrm{g}$ of protein per sample) were subjected to immunoblot analysis using antibodies against total alpha-synuclein (Syn immunoblot, C20-R and Syn-1), phosphorylated alpha-synuclein (P-Syn immunoblot) and PGP 9.5 (PGP 9.5 immunoblot). The optical densities of (C) total alpha-synuclein (C2O-R) and (B) phosphorylated alpha-synuclein immunoreactive bands were measured, normalized to

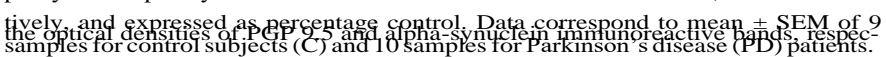
No significant changes were observed between the two groups, $(p=0.9$ and 0.75 , respectively).

were fixed with $0.4 \%(\mathrm{v} / \mathrm{v})$ paraformaldehyde (PFA, Sigma) for $30 \mathrm{~min}$ and alpha-synuclein immublotting was performed as previously described [13].

\section{Results}

In a first set of experiments, we analyzed by Western blotting the expression levels and phosphorylation status of alpha-synuclein in colonic biopsies from control and PD subjects. A band migrating to $15 \mathrm{kDa}$ on Western blot was observed using (C20)-R and Syn1 antibodies that recognize different epitopes on alpha-synuclein, thus confirming its identity (Fig. 1A). In some samples, a faster migrating 12-13 kDa band was also observed (Fig. 1A). Such a band has already been described in platelets [15] and cerebrospinal fluid [16] and might correspond to a caspase-truncated form of the protein [17]. Despite equal protein loading, the $15-\mathrm{kDa}$ alphasynuclein band density was extremely variable (Fig. 1A), with no significant difference between PD patients and controls being found when alpha-synuclein amounts were normalized to PGP 9.5 in each sample (Fig. 1C). Phosphorylated alpha-synuclein was identified in all PD and control samples (Fig. 1A), but in both groups the amount detected was also highly variable and following normalization to total alpha-synuclein no significant differences were found between PD and control cases (Fig. 1B). No difference in the immunoreactivity of the $12-13 \mathrm{kDa}$ band was observed between PD and controls (data not shown).

The small amount of pathological aggregated and hyperphosphorylated alpha-synuclein present in biopsy samples may have remained largely unsolubilized because of the relatively low-stringency buffer that was used in our one-dimenional immunoblotting experiments. This prompted us to perform a second set of experiments in which samples were lysed with the high stringency UTC buffer then subsequently analyzed by twodimensional immunoblotting. As previously reported [3], we first showed that this technique was capable of detecting a series of alpha-synuclein species that are unique to DLB brain when compared to control brain, including high molecular weight alphasynuclein species as well as acidic full-length species (Fig. 2A). However, when this technique was applied to colonic biopsies, the patterns from control subjects and PD patients were qualitatively indistinguishable from each other, with only total unmodified alpha-synuclein being detected in both conditions (Fig. 2B and supplementary Fig. 1).

\section{Discussion}

Based on the topographic distribution of Lewy bodies and neurites established after autopsy from PD patients, Braak and coworkers hypothesized that the gastrointestinal tract and the olfactory bulb might be trigger sites of alpha-synuclein pathology $[18,19]$. The pathology would then subsequently spread to the brainstem via the vagus nerve and connected brain regions [20]. This hypothesis has been reinforced by the discovery that alpha-synuclein is capable of spreading transcellularly in a "prionlike" manner, thereby providing a cellular basis to Braak's staging scheme that describes PD progression [21]. These 'gut to brain' and 'nose to brain' scenarios have ignited heated debates within the movement disorders community and have prompted a large number of studies in both humans and animals. Two recent studies showed that injection of fibrillar alpha-synuclein into the intestinal wall [22] or into the olfactory bulb [23] in rodents leads to propagation of alpha-synuclein pathology in the brain. In human, the accessibility of both the olfactory and enteric nervous systems to biopsies led to interest in utilizing these tissues as more accessible biomarker material for PD and a substantial amount of research has now been conducted to develop original histopathological markers of PD in these tissues [24,25]. Being the only component of the olfactory system accessible to biopsy, the olfactory epithelium has been screened for Lewy pathology. Several independent autopsy studies showed that alpha-synuclein deposits were observed in the olfactory mucosa in subjects with PD [26-29]. However, a pilot in vivo study reported no evidence of disease-specific pathology in the olfactory epithelium in seven hypo/anosmic PD patients [30]. Conflicting results have been gained following analysis of gastrointestinal biopsies, all of which have used immunohistochemical methods to detect alpha-synuclein, and there is not yet any fully validated biochemical method for detecting aggregated and/or phosphorylated alpha-synuclein in peripheral tissues [12,31].

Despite the growing interest in peripheral tissue for the detection of PD pathology [24], very few studies have used biochemical approaches including immunoblotting to examine pathological alpha-synuclein in peripheral autonomic networks. One likely explanation is that alpha-synuclein detection by Western blot has proven difficult because the protein is easily washed off from both PVDF or nitrocellulose membranes, making it difficult to detect especially in tissues expressing low levels of the protein [32]. This prompted several groups to develop methods for improving alpha-synuclein retention on blot membranes by increasing its hydrophobicity. This included fixation of membranes with PFA 
A

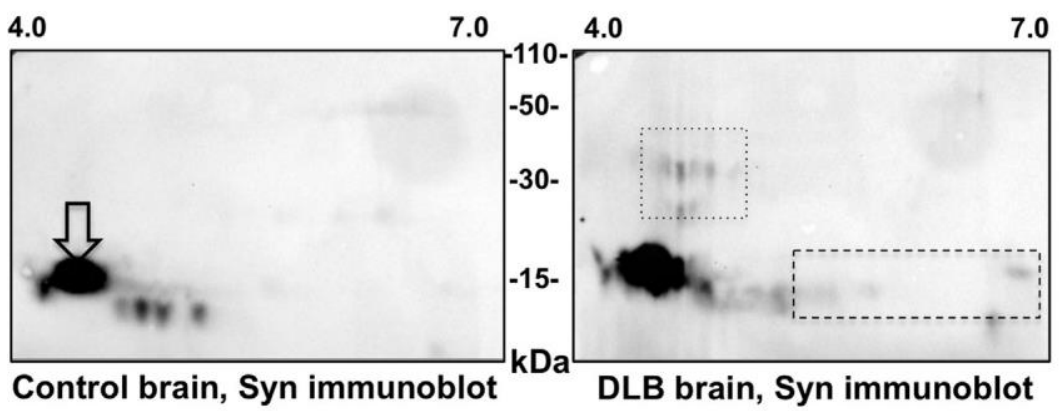

B

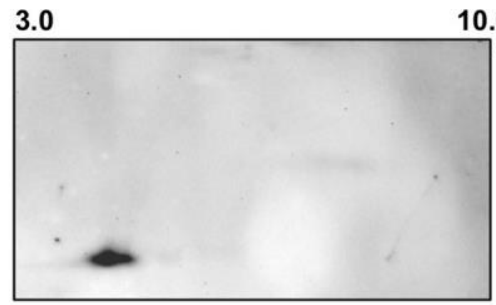

Control colonic biopsy (C10) Syn immunoblot
10.0

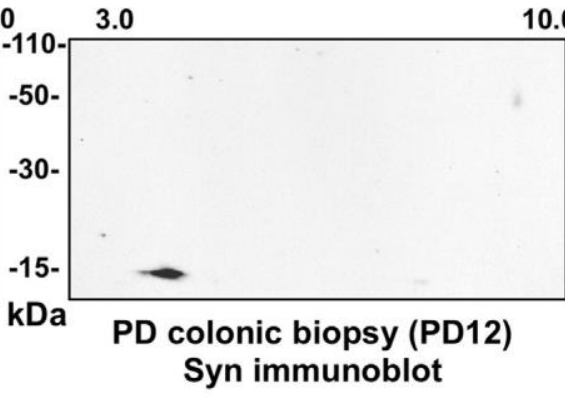

3.0

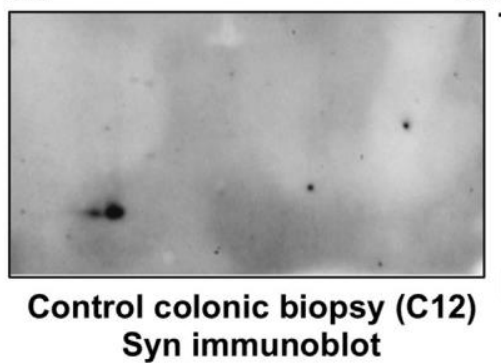

3.0

10.0

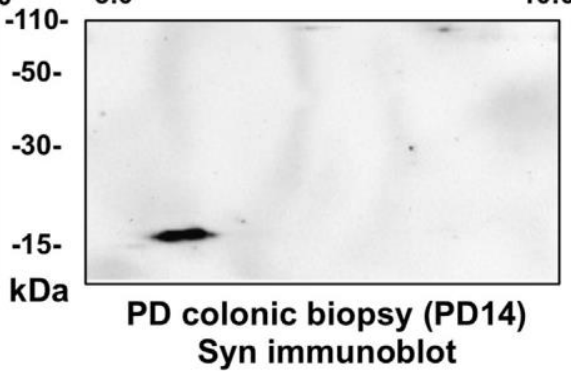

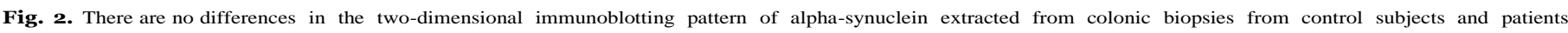

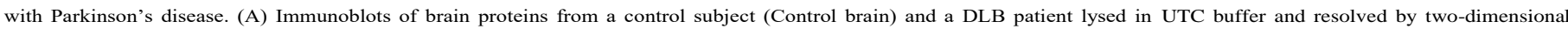

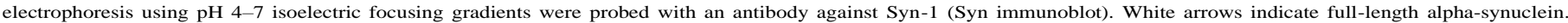

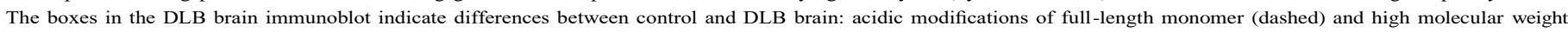

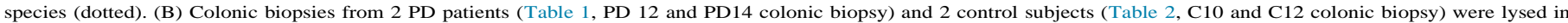

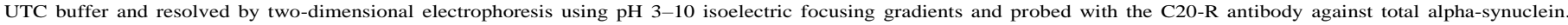
The figure shown is representative of the 2-D immunoblot experiments performed in 7 PD and 4 control subjects.

or treatment of samples with the cross-linker DSP [14,32]. We have recently shown that these two methods are indeed efficient at improving the sensitivity of western blotting to detect alphasynuclein immunoreactivity in gut samples or primary ENS cultures [13].

We therefore took advantage of these two methods to analyze the expression levels and the phosphorylation status of alpha-synuclein in colonic biopsies from control and PD subjects. The cross-linker DSP was used in experiments involving one-dimensional immunoblotting while PFA-membrane fixation was used in conjunction with two-dimensional immunoblotting. Using one-dimensional immunoblotting, we showed that alphasynuclein was detected in samples from all PD and control samples, however in both groups the amounts detected were highly variable and no differences between groups were found following normalization of alpha-synuclein amounts to that of the neuronal marker
PGP 9.5. Given that alpha-synuclein is found in nerve terminals and cell bodies of submucosal neurons captured by the biopsy forceps [3335], it might be postulated that this variability between biop- sies relates to variation in the tissues sampled including omission of submucosal neuronal processes [12]. Immunoreactivity for phosphorylated alpha-synuclein was also observed in PD and control, a finding that is likely to explained by the fact that a small amount (around $4 \%$ ) of alpha-synuclein is physiologically phosphorylated at serine 129 in the brain [36] and in the gut [34]. After quantification of phosphorylated alpha-synuclein amounts as a proportion of total alpha-synuclein, we did not observe any difference between PD and healthy subjects.

Two-dimensional immunoblotting is a sensitive technique for identifying protein posttranslational modifications and aggregates, and we therefore used this technique to assess a second set of colonic samples. As previously reported, this approach enabled 
the detection of acidic and high molecular weight alpha-synuclein species in DLB brain, that likely represent hyperphosphorylated and aggregated forms of the protein, respectively [3]. However, these species were not observed in colonic samples from PD subjects, which contained only full-length unmodified alpha-synuclein.

Overall, our study suggests that the two biochemical methods investigated here are not sufficient to detect pathological alphasynuclein species in gastrointestinal biopsies, and therefore have limited utility for predicting PD. This may be due to the relative rarity of neuronal structures and/or alpha-synuclein inclusions in the gastrointestinal samples analyzed, or as a result of the relatively low sensitivity of the methods tested. Such limitations could be overcome in future studies by using ultrasensitive techniques such as protein misfolding cyclic amplification (PMCA) and real-time quaking-induced conversion (RT-QuIC) assays, which have been recently shown to efficiently amplify aggregated alpha-synuclein $[37,38]$.

\section{Conflict of interest}

The authors declare no actual or potential conflict of interest.

\section{Author's contribution}

EC performed the colonoscopy and biopsies in PD patients. MRD performed the biopsies for control individuals. AGC, CP and TL performed and analyzed the biochemical experiments. PD and MN designed the study. PD supervised the study, wrote the first draft and the final version of the manuscript.

\section{Acknowledgements and sources of support}

This work was supported by a grant from centre d'entraide et de coordination des associations de parkinsoniens (CECAP) and by a Master's grant of DHU2020 to PD. AGC is a recipient of a poste d'accueil Inserm. We thank Dr. Wendy Noble, Institute of Psychiatry, King's College, London, UK, for language editing.

\section{Appendix A. Supplementary data}

Supplementary data associated with this article can be found, in the online version, at http://dx.doi.org/10.1016/j.neulet.2017.01. 050 .

\section{References}

[1] M.G. Spillantini, R.A. Crowther, R. Jakes, M. Hasegawa, M. Goedert, Alpha-synuclein in filamentous inclusions of Lewy bodies from Parkinson's disease and dementia with lewy bodies, Proc. Natl. Acad. Sci. U.S.A. 95 (1998) 6469-6473.

[2] H. Fujiwara, M. Hasegawa, N. Dohmae, A. Kawashima, E. Masliah, M.S. Goldberg, et al., Alpha-synuclein is phosphorylated in synucleinopathy lesions, Nat. Cell Biol. 4 (2002) 160-164.

[3] J.P. Anderson, D.E. Walker, J.M. Goldstein, R. de Laat, K. Banducci, R.J. Caccavello, et al., Phosphorylation of Ser-129 is the dominant pathological modification of alpha-synuclein in familial and sporadic Lewy body disease, J. Biol. Chem. 281 (2006) 29739-29752

[4] T.G. Beach, C.H. Adler, L.I. Sue, L. Vedders, L. Lue, C.L. White Iii, et al., Multi-organ distribution of phosphorylated alpha-synuclein histopathology in subjects with Lewy body disorders, Acta Neuropathol. 119 (2010) 689-702

[5] T.G. Beach, A.-G. Corbillé, F. Letournel, J.H. Kordower, T. Kremer, D.G. Munoz, et al., Multicenter assessment of immunohistochemical methods for pathological alpha-Synuclein in sigmoid colon of autopsied parkinson's disease and control subjects, J. Parkinson's Dis. 6 (2016) 761-770.

[6] T. Lebouvier, T. Chaumette, P. Damier, E. Coron, Y. Touchefeu, S. Vrignaud, et al., Pathological lesions in colonic biopsies during Parkinson's disease, Gut 57 (2008) 1741-1743, http://dx.doi.org/10.1136/gut.2008.162503.

[7] T. Lebouvier, M. Neunlist, S. Bruley des Varannes, E. Coron, A. Drouard, J.-M Nguyen, et al., Colonic biopsies to assess the neuropathology of Parkinson's disease and its relationship with symptoms, PLoS One 5 (2010) e12728.
[8] H. Pouclet, T. Lebouvier, E. Coron, S.B. des Varannes, T. Rouaud, M. Roy, et al., A comparison between rectal and colonic biopsies to detect Lewy pathology in Parkinson's disease, Neurobiol. Dis. 45 (2012) 305-309.

[9] N.P. Visanji, C. Marras, D.S. Kern, A. Al Dakheel, A. Gao, L.W.C. Liu, et al, Colonic mucosal a-synuclein lacks specificity as a biomarker for Parkinson disease, Neurology 84 (2015) 609-616.

[10] K.M. Shannon, A. Keshavarzian, E. Mutlu, H.B. Dodiya, D. Daian, J.A. Jaglin, et al., Alpha-synuclein in colonic submucosa in early untreated Parkinson's disease, Mov. Disord. 27 (2012) 709-715

[11] D. Hilton, M. Stephens, L. Kirk, P. Edwards, R. Potter, J. Zajicek, et al., Accumulation of a-synuclein in the bowel of patients in the pre-clinical phase of Parkinson's disease, Acta Neuropathol. 127 (2013) 235-241.

[12] A.-G. Corbillé, F. Letournel, J.H. Kordower, J. Lee, E. Shanes, M. Neunlist, et al., Evaluation of alpha-synuclein immunohistochemical methods for the detection of Lewy-type synucleinopathy in gastrointestinal biopsies, Acta Neuropathol. Commun. 4 (2016) 35

[13] C. Preterre, A.-G. Corbillé, G. Balloy, F. Letournel, M. Neunlist, P. Derkinderen, Optimizing western blots for the detection of endogenous a-synuclein in the enteric nervous system, J, Parkinson's Dis. 5 (2015) 765-772.

[14] A.J. Newman, D. Selkoe, U. Dettmer, A new method for quantitative immunoblotting of endogenous a-synuclein, PLoS One 8 (2013) e81314

[15] Q.-X.Li, B.C.V.Campbell, C.A. McLean, D. Thyagarajan, W.P. Gai, R.M. Kapsa, et al., Platelet alpha- and gamma-synucleins in Parkinson's disease and normal control subjects, J. Alzheimers Dis. 4 (2002) 309-315.

[16] R. Borghi, R. Marchese, A. Negro, L. Marinelli, G. Forloni, D. Zaccheo, et al., Full length alpha-synuclein is present in cerebrospinal fluid from Parkinson's disease and normal subjects, Neurosci. Lett. 287 (2000) 65-67.

[17] W. Wang, L.T.T. Nguyen, C. Burlak, F. Chegini, F. Guo, T. Chataway, et al., Caspase- 1 causes truncation and aggregation of the Parkinson's disease-associated protein a-synuclein, Proc. Natl. Acad. Sci. U. S. A. 113 (2016) 9587-9592.

[18] H. Braak, K. Del Tredici, U. Rüb, R.A.I. de Vos, E.N.H. Jansen Steur, E. Braak, Staging of brain pathology related to sporadic Parkinson's disease, Neurobiol. Aging 24 (2003) 197-211.

[19] H. Braak, R.A.I. de Vos, J. Bohl, K. Del Tredici, Gastric alpha-synuclein immunoreactive inclusions in Meissner's and Auerbach's plexuses in cases staged for Parkinson's disease-related brain pathology, Neurosci. Lett. 396 (2006) 67-72

[20] H. Braak, K. Del Tredici, Potential pathways of abnormal tau and a-synuclein dissemination in sporadic alzheimers and parkinsons diseases, Cold Spring Harb. Perspect. Biol. 8 (2016) a023630, http://dx.doi.org/10.1101/cshperspect. a023630.

[21] P. Brundin, J. Ma, J.H. Kordower, How strong is the evidence that Parkinson's disease is a prion disorder? Curr. Opin. Neurol. 29 (2016) 459-466.

[22] S. Holmqvist, O. Chutna, L. Bousset, P. Aldrin-Kirk, W. Li, T. Björklund, et al., Direct evidence of Parkinson pathology spread from the gastrointestinal tract to the brain in rats, Acta Neuropathol. 128 (2014) 805-820.

[23] N.L. Rey, J.A. Steiner, N. Maroof, K.C. Luk, Z. Madaj, J.Q. Trojanowski, et al., Widespread transneuronal propagation of a-synucleinopathy triggered in olfactory bulb mimics prodromal Parkinson's disease, J. Exp. Med. 213 (2016) $1759-17784$.

[24] T. Lebouvier, M. Tasselli, S. Paillusson, H. Pouclet, M. Neunlist, P. Derkinderen, Biopsable neural tissues: toward new biomarkers for Parkinson's disease? Front. Psychiatry 1 (2010) 128.

[25] J.M. Lee, P. Derkinderen, J.H. Kordower, R. Freeman, D.G. Munoz, T. Kremer, et al., The search for a peripheral biopsy indicator of a-Synuclein pathology for parkinson disease, J. Neuropathol. Exp. Neurol. (2017) nlw103, http://dx. doi.org/10.1093/jnen/nlw103.

[26] J.E. Duda, U. Shah, S.E. Arnold, V.M. Lee, J.Q. Trojanowski, The expression of alpha- beta-, and gamma-synucleins in olfactory mucosa from patients with and without neurodegenerative diseases, Exp. Neurol. 160 (1999) 515-522.

[27] S.E. Arnold, E.B. Lee, P.J. Moberg, L. Stutzbach, H. Kazi, L.-Y. Han, et al., Olfactory epithelium amyloid-beta and paired helical filament-tau pathology in Alzheimer disease, Ann. Neurol. 67 (2010) 462-469.

[28] Y. Saito, A. Shioya, T. Sano, H. Sumikura, M. Murata, S. Murayama, Lewy body pathology involves the olfactory cells in Parkinson's disease and related disorders, Mov. Disord. 31 (2016) 135-138.

[29] S. Funabe, M. Takao, Y. Saito, H. Hatsuta, M. Sugiyama, S. Ito, et al., Neuropathologic analysis of Lewy-related a-synucleinopathy in olfactory mucosa, Neuropathology 33 (2013) 47-58.

[30] M. Witt, K. Bormann, V. Gudziol, K. Pehlke, K. Barth, A. Minovi, etal, Biopsies of olfactory epithelium in patients with Parkinson's disease, Mov. Disord. 24 (2009) 906-914.

[31] A.-G. Corbillé, T. Clairembault, E. Coron, L. Leclair-Visonneau, C. Preterre, M Neunlist, et al., What a gastrointestinal biopsy can tell us about Parkinson's disease, Neurogastroenterol. Motil. 28 (2016) 966-974.

[32] B.R. Lee, T. Kamitani, Improved immunodetection of endogenous a-synuclein, PLoS One 6 (2011) e23939.

[33] M. Böttner, D. Zorenkov, I. Hellwig, M. Barrenschee, J. Harde, T. Fricke, et al., Expression pattern and localization of alpha-synuclein in the human enteric nervous system, Neurobiol. Dis. 48 (2012) 474-480.

[34] M. Barrenschee, D. Zorenkov, M. Böttner, C. Lange,F. Cossais, A.B. Scharf, etal., Distinct pattern of enteric phospho-alpha-synuclein aggregates and gene expression profiles in patients with Parkinson's disease, Acta Neuropathol. Commun. 5 (2017) 1. 
[35] H. Pouclet, T. Lebouvier, E. Coron, S. B. des Varannes, M. Neunlist, P. Derkinderen, A comparison between colonic submucosa and mucosa to detect Lewy pathology in Parkinson's disease, Neurogastroenterol. Motil. 24 (2012) e202-5.

[36] Y. Hirai, S.C. Fujita, T. Iwatsubo, M. Hasegawa, Phosphorylated

alpha-synuclein in normal mouse brain, FEBS Lett. 572 (2004) 227-232

[37] G. Fairfoul, L.I. McGuire, S. Pal, J.W. Ironside, J. Neumann, S. Christie, et al. Alpha-synuclein RT-QuIC in the CSF of patients with alpha-synucleinopathies, Ann. Clin. Transl. Neurol. 3 (2016) 812-818.
[38] M. Shahnawaz, T. Tokuda, M. Waragai, N. Mendez, R. Ishii, C. Trenkwalder, et al., Development of a biochemical diagnosis of parkinson disease by detection of a-synuclein misfolded aggregates in cerebrospinal fluid, JAMA Neurol. (2016), http://dx.doi.org/10.1001/jamaneurol.2016.4547. 